\title{
OUT-OF SCHOOL \& NON-FORMAL EDUCATION: UKRAINIAN AND EUROPEAN DIMENSIONS
}

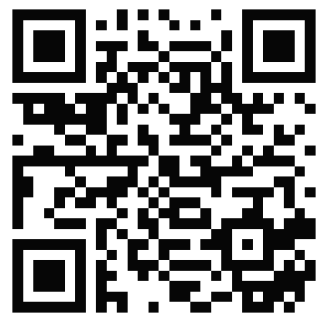

To cite this article:

\author{
Olena Lytovchenko, PhD \\ Senior Researcher, Laboratory of Out-of School Education, \\ Institute of Problems on Education, \\ National Academy of Educational Sciences of Ukraine, \\ Kyiv, Ukraine \\ elenalitovchenko@ukr.net \\ https://orcid.org/0000-0001-8696-9610 \\ Lytovchenko, O. (2020). Out-of school \& non-formal \\ education: Ukrainian and European dimensions. \\ Education: Modern Discourses, 3, 50-55. \\ https://doi.org/10.37472/2617-3107-2020-3-05
}

\begin{abstract}
Out-of-school education in Ukraine has its own traditions and experience, at the same time, develops in the context of European trends, adopts the best foreign practices, in particular, institutions and organizations of non-formal education in European countries. Out-of-school education in Ukraine and non-formal education in European countries have significant differences, but similar goals and values. The purpose of the paper is to present the results of the study of common goals and values of out-of-school education in Ukraine and nonformal education in European countries, as well as to analyze the regulatory aspects, practical experience. According to the results of the analysis, the common goals and values of out-ofschool education in Ukraine and non-formal education in European countries include: providing children and youth with opportunities for non-formal and informal learning, creating conditions for leadership, communication, language learning, teamwork, social roles, development of critical thinking, self-awareness and awareness of others, responsibility; socialization, creative realization and professional self-determination of children and youth as well as promoting active citizenship, supporting youth activities.
\end{abstract}

Key words: goals and values; informal learning; non-formal education; out-of school education of Ukraine; UNESCO.

\section{INTRODUCTION}

Ukrainian education develops in the context of European educational trends, adopts the best European experience. The reform of Ukrainian education is reflected in the improvement of regulatory support.

Among the main normative principles of Ukrainian education today are the Concept of the New Ukrainian School (2016), the Law of Ukraine "On Education" (2017) and other documents. In particular the law stipulates that education is the basis of intellectual, spiritual, physical and cultural development of the individual, the key to the development of a society united by common values and culture, and the state. The Law of Ukraine "On Education" includes the terms "formal education", "non-formal education", "informal education", while 
retaining the term "out-of-school education". This is very important for the development of out-of-school education in Ukraine.

Out-of-school education is an educational subsystem, educational programs in out-ofschool education in accordance with Art. 10 of the Law of Ukraine "On Education" (2017) may provide for the acquisition of partial qualifications. Therefore, they are important in ensuring the rights of citizens to education, professional knowledge and skills. According to experts, the transfer of out-of-school education in Ukraine to the status of non-formal can reduce its importance, negatively affect the content and results.

\section{LITERATURE REVIEW}

In the context of the problem, the theoretical provisions of psychological and pedagogical science of Ukraine are important, in particular, devoted to the education of children and youth in various educational institutions and social institutions (Teoretyko-metodychni problemy vykhovannia ditei ta uchnivskoi molodi, 2016).

Pustovit (2012, 2017), Verbickiy (2019) and others are devoted to the theoretical and methodological foundations of out-of-school education. The collective monograph «Optimization of the educational potential of an out-of-school educational institution» (Verbickiy et al., 2012) highlights the historical aspects and current trends in the development of out-of-school education in Ukraine, gives examples of the activities of out-of-school education institutions. The analysis of the potential of the educational environment of out-ofschool education institutions was also carried out.

The activities of non-formal education institutions are considered in studies by Clarijs (2008) and others. In particular, Clarijs (2008) analyzed non-formal education in European countries within the project of the European Association of Institutions of Non-formal Education of Children and Youth, summarized two main concepts of development, identified commonalities and differences.

Significant within the research problem are the provisions of international UNESCO documents (Education for All (EFA) Framework Program (Dakar) (2000); Memorandum on Continuing Education of the European Union (2000); Decision of the Prague Summit of Ministers of Education and Science European countries to supplement the Bologna Declaration of 1999 with the concept of lifelong learning (2001); Resolution of the European Council on Lifelong Learning (2004).

The purpose of the paper is to present the results of the study of common goals and values of out-of-school education in Ukraine and non-formal education in European countries, as well as to analyze the regulatory aspects, practical experience.

\section{METHODOLOGY}

By analyzing Ukrainian and foreign sources, regulations, as well as analyzing and comparing the experience of practical activities of out-of-school education institutions, the common goals and values of out-of-school education in Ukraine and non-formal education in European countries have been identified.

In particular, the Laws of Ukraine "On Education" (2017), "On Out-of-school Education" (2000) on the goals and organizational framework of out-of-school education in Ukraine are analyzed.

UNESCO documents on non-formal education are analyzed, in particular the definition of non-formal education, its priorities. 


\section{MAIN RESULTS}

Out-of-school education in Ukraine is an important educational subsystem defined by the Laws of Ukraine "On Education" (2017), "On Out-of-school Education" (2000).

The Law of Ukraine "On Education” (2017) defines out-of-school education as an integral part of the education system of Ukraine; Article 15 stipulates that the purpose of extracurricular education is to develop the abilities of children and youth in education, science, culture, physical culture and sports, technical and other creativity, their acquisition of primary professional knowledge, skills and abilities necessary for their socialization, further self-realization and / or professional activity; competencies acquired in extracurricular education programs can be taken into account and recognized at the appropriate level of education.

The Law of Ukraine "On Out-of-school Education" (2000) defines the main objectives of out-of-school education:

- education of a citizen of Ukraine;

- free development of personality and formation of its social and public experience;

- fostering a sense of self-worth, responsibility before the law for their actions;

- education of love for Ukraine, respect for folk customs, traditions, national values of the Ukrainian people, as well as other nations and peoples;

- creating conditions for creative, intellectual, spiritual and physical development of students;

- development of an inclusive educational environment in out-of-school education institutions;

- acquisition by students of primary professional skills and abilities;

- formation of a conscious and responsible attitude to one's own health and the health of others, skills of safe behavior;

- development and support of gifted and talented students;

- organization of students' leisure and others.

In this context, out-of-school education is an important educational institution for the education and socialization of children and youth, creates conditions for value selfdetermination, social development and creative self-realization of the individual, and promotes social security and professional orientation of students.

The study of the goals and values of out-of-school education in Ukraine in our study is based on the works of Ukrainian scientists (Pustovit, 2012; Verbickiy, 2019); analysis of the experience of out-of-school education institutions (Rivne Palace of Children and Youth and others). In particular, in the research of Pustovit (2012) it is determined that the essential basis of education, development, socialization of the individual in out-of-school education institutions is variability, voluntariness, practical orientation of the educational process; in modern conditions, out-of-school education should become a means of reviving national culture, educating such moral qualities as conscience, patriotism, humanity, self-esteem, creative initiative, responsibility.

The goals and values of out-of-school education in Ukraine can be determined by analyzing the practical activities of out-of-school education institutions. One of the many examples of successful activities is the Rivne Palace of Children and Youth. The structure of the institution includes specialized schools (business, modern choreography, pop and vocal art, fine arts, computer science, folk dance, sports dance, intellectual sports, martial arts, leader), specialized centers, clubs and associations, art groups. Thus, an important area of activity of the institution is socialization, creative realization and professional self-determination of children and youth.

The values of humanism, responsibility, mutual support are demonstrated by the traditional event of the Palace - Charity Marathon "With faith in the future". This event unites 
all the teams, all the students of the Palace. During the month there are auctions, concerts, flash mobs, promotions, performances and more. The funds raised are traditionally donated to support the best students of the Palace, to realize their dreams. And also to help those who need it. The 25th Charity Marathon "With Faith in the Future" in 2020 took place during the COVID-19 pandemic in online format (broadcast of TV versions of concerts art groups on TV channels and on Facebook, online auction of creative works of students of the School of Fine Arts, flash mob and challenges).

The promotion of common European values among children and young people is facilitated by the activities of Euro clubs in out-of-school education institutions. For example, in the structure of the Kirovohrad regional center of children's and youth creativity there is a Euro club «Nadiya». The main goal is to actively promote the idea of European and world unity, active citizenship. The achievements of the team are the organization and holding of the regional project "Europe without Borders", "Democratic School", "Start doing good", "Tolerance as the face of the modern world", the stage of the International competition "Safe Ukraine". "Safe Europe. Safe World" and more.

Out-of-school education has its own traditions and experience, at the same time, it develops in the context of European trends, adopts the best foreign practices, in particular, institutions and organizations of non-formal education in European countries.

Various terms are used in the world, in particular: "non-formal education", "informal learning", "out-of-school education", "leisure programs" and others.

The UNESCO Glossary interprets the terms as follows:

Informal learning - Forms of learning that are intentional or deliberate but are not institutionalized. They are less organized and structured than either formal or non-formal education. Informal learning may include learning activities that occur in the family, in the work place, in the local community, and in daily life, on a self-directed, family-directed or socially-directed basis.

Non-formal education - Education that is institutionalized, intentional and planned by an education provider. The defining characteristic of non-formal education is that it is an addition, alternative and/or a complement to formal education within the process of the lifelong learning of individuals. It is often provided to guarantee the right of access to education for all. It caters for people of all ages, but does not necessarily apply a continuous pathway-structure; it may be short in duration and/or low intensity, and it is typically provided in the form of short courses, workshops or seminars. Non-formal education mostly leads to qualifications that are not recognized as formal qualifications by the relevant national educational authorities or to no qualifications at all. Non-formal education can cover programmes contributing to adult and youth literacy and education for out-of-school children, as well as programmes on life skills, work skills, and social or cultural development.

Non-formal education for Europeans is part of the concept of long life education, which allows young people and adults to acquire and maintain at the appropriate level the skills and competencies needed to adapt to an ever-changing environment.

Non-formal education of children and youth, which is part of non-formal education, has its peculiarities in European countries. In particular, Clarijs (2008) reduces the concepts of non-formal education available in Europe to two dominant types:

- The concept of care - is dominant mainly in Western Europe, where there is a developed guardianship system, almost all financial assistance from national and local governments, focused on the needs of young people, is directed to children and young people with serious problems. In these countries, the government is practically focused on the problem part of society (5-10\% of children). The consequence of this approach, according to Clarijs (2008), is that every year more and more children need help because not enough attention is paid to prevention.

- The concept of development is more typical for the countries of Eastern and Central 
Europe. Society here is less interested in the guardianship system, preferring to invest in the interests of a larger group of children, those who have no problems.

Institutions of non-formal education of children and youth of different countries have significant differences; develop in different economic and socio-cultural conditions. However, they mostly have similar goals and values. According to Clarijs (2008), the key words for nonformal education are "competences" and "skills". Examples of "skills" of non-formal education are leadership, communication, language learning, teamwork, learning social roles, conflict resolution, critical thinking, self-awareness and awareness of others, responsibility, etc. (Table 1).

Table 1

\section{Commonalities and differences non-formal education of children and youth in European countries}

\begin{tabular}{|c|c|}
\hline \multicolumn{2}{|c|}{ Differences in concept } \\
\hline $\begin{array}{l}\text { Care concept } \\
\text { - mainly in Western Europe; } \\
\text { - almost all financial assistance from national and } \\
\text { local governments, focused on the needs of young } \\
\text { people, is directed to children and young people } \\
\text { with serious problems; } \\
\text { - not enough attention is paid to problem } \\
\text { prevention }\end{array}$ & $\begin{array}{l}\text { Development concept } \\
\text { - specific to the countries of Eastern and Central } \\
\text { Europe; } \\
\text { - the state and society invest in the interests of a } \\
\text { larger group of children; } \\
\text { - more attention is paid to social prevention }\end{array}$ \\
\hline \multicolumn{2}{|c|}{ Common goals and values } \\
\hline $\begin{array}{l}\text { Creating conditions for the development } \\
\text { leadership, communication, language learning, act } \\
\text { social roles, conflict resolution, critical thinking, s } \\
\text { and more }\end{array}$ & $\begin{array}{l}\text { of skills and competencies of children and youth: } \\
\text { ive listening, planning, teamwork, empathy, learning } \\
\text { elf-awareness and awareness of others, responsibility }\end{array}$ \\
\hline
\end{tabular}

In this context, the activities of the European Association of Institutions of Non-formal Education of Children and Youth are important.

European Association for Leisure Time Institutions of Children and Youth (EAICY) (modern name - European Association of Institutions of Non-formal Education of Children and Youth) was founded in 1991 with the aim of creating a single information space, developing European cooperation in non-formal education, mutual enrichment of experience of leisure organizations. EAICY is an advisory member of the Council of Europe and has a permanent representative in Strasbourg. EAICY is headquartered in Prague (Czech Republic).

The Association includes representatives of 16 European countries. Thus, the members of the Association are centers for work with children and youth of France, Italy, Germany, the Netherlands, the Czech Republic, Poland, Portugal, Ukraine, Georgia, Kazakhstan, Latvia, Lithuania and others. One of the founders of the Association as a representative of Ukraine was the Kyiv Palace of Children and Youth; Since 2007, the Association of Out-of-School Educational Institutions of Ukraine has become a collective member of this organization. Today, the Kyiv Palace of Children and Youth, the Rivne Palace of Children and Youth and other institutions are active members of the organization.

Examples of programs involving European non-formal education institutions and outof-school education institutions in Ukraine are the European Union's youth programs such as "Lifelong Learning", "Youth in Action", which is the successor to the "Youth for Europe" and "Youth" programs, etc. Such programs are based on non-formal education and are a key tool that provides young people with opportunities for non-formal and informal learning on the 
European dimension. In particular, the "Youth in Action" Program aims to: promote active youth citizenship in general and European citizenship in particular; to develop solidarity and tolerance between young people, especially to strengthen social ties in the European Union; to strengthen mutual understanding between young people from different countries; to promote the development of quality systems to support youth activities and the viability of public organizations in the youth sphere; to disseminate European cooperation in the youth sphere.

\section{CONCLUSIONS}

Thus, out-of-school education in Ukraine is developing in the context of European trends, perceives European values, which are implemented, in particular, by non-formal education institutions for children and youth of European countries. Among the common goals and values of extracurricular education in Ukraine and non-formal education in European countries are: providing children and young people with opportunities for non-formal and informal learning, creating conditions for leadership, communication, language learning, teamwork skills, learning social roles, developing critical thinking, self-awareness and awareness of others, responsibility; socialization, creative realization and professional self-determination of children and youth as well as promoting active citizenship, supporting youth activities.

\section{REFERENCES}

Clarijs, Renй (ed.). (2008). Leisure \& Non-formal Education. A European Overview of After-and Out-of-School Education. Prague, Czech Republic: EAICY

European Association of Institutions of Non-formal Education of Children and Youth. Retrieved 2020 from: http://www.eaicy.cz/

Ministerstvo osvity i nauky Ukrainy. (2016). Nova ukrainska shkola: kontseptualni zasady reformuvannia serednoi shkoly [Ministry of Education and Science of Ukraine. (2016). The new Ukrainian school: conceptual principles of secondary school reform]. Hryshchenko M. (Ed.). Retrieved 2020 from: https://mon.gov.ua/storage/app/media/zagalna\%20 serednya/nova-ukrainska-shkola-compressed.pdf (in Ukrainian)

Pustovit, G.P. (2012). Pozashkilna osvita i vihovannia. Pidruchnik. [Out-of-school education and upbringing. Textbook]. Kyiv: Pedagogichna dumka. (in Ukrainian)

Pustovit, G. (ed.). (2017). Enciclopedia pozashkilnoy osviti [Out-of-school education enciclopedia]. Rivne. (in Ukrainian)

Teoretyko-metodychni problemy vykhovannia ditei ta uchnivskoi molodi [Theoretical and methodological problems of education of children and pupils' youth]. Vol. 20 (1). 2016. Kyiv. (in Ukrainian)

United Nations Educational, Scientific and Cultural Organization (UNESCO). Retrieved 2020 from: https://ru.unesco.org/

UNESCO Glossary. Retrieved 2020 from: http://uis.unesco.org/en/glossary

Verbickiy, V., Machuskiy, V., Kornienko, A., Boyko, A. \& Lytovchenko, O. (eds.). (2012). Optimizacia vihovnogo potencialu pozashkilnogo navchalnogo zakladu [Optimization of the educational potential of an out-of-school educational institution]. Kyiv: Pedagogichna dumka. ( in Ukrainian)

Verbickiy, V. (2019). Shlyahi realizaciii clyuchovoi reformi Nova ukrainska shkola v pozashkilli. [Implementation of the key reform New Ukrainian school in out-of-school]. Osobistist $u$ prostori vihovnih innovaciy, 59-63. (in Ukrainian)

Zakon Ukrainy "Pro osvitu". (2017). [Law of Ukraine "On education"]. Retrieved 2020 from: http://zakon2.rada.gov.ua/laws/ (in Ukrainian)

Zakon Ukrainy "Pro pozashkilnu osvitu". (2000). [Law of Ukraine "On out-of-school education"]. Retrieved 2020 from: http://zakon2.rada.gov.ua/laws/ (in Ukrainian) 